\title{
In vitro allelopathic effect of aqueous extracts of sugarcane on germination parameters of wheat
}

\author{
Abdul MAJEED ${ }^{1 *}$, Zahir MUHAMMAD ${ }^{2}$, Manzoor HUSSAIN $^{3}$ and Habib AHMAD ${ }^{4}$
}

Received January 26, 2017; accepted March 27, 2017.

Delo je prispelo 26. januarja 2017, sprejeto 27. marca 2017.

\begin{abstract}
Allelopathy - interactions among plants for resources along with competition - is a composite phenomenon which has spacious potentials of application in agriculture. Understanding of interactions among plants, particularly cultivated crops, may be helpful in modifying crop cultivation pattern with consequent yields increments. In this study, we investigated the allelopathic effects of aqueous extracts of root, stem peels and leaves of sugarcane (Saccharum officinale L.) cultivar 51 at concentrations $0,2.5,5.0,7.5$ and $10.0 \mathrm{~g} / \mathrm{l}$ on germination indices and seedling biomass of wheat (Triticum aestivum L.) cultivar Pirsabak-2005. Results demonstrated that higher concentration $(10.0 \mathrm{~g} / \mathrm{l})$ of extracts of root, stem peels and leaves significantly decreased mean germination time (MGT) but increased shoot and seminal root growth and seedling dry biomass; however, germination percentage was affected neither by extract concentration nor by plant parts used in the study. Extract concentrations up to $7.5 \mathrm{~g} / \mathrm{l}$ had no effect on the studied parameters of wheat. Our result suggests that sugarcane's allelopathy demonstrates healthy effects on wheat growth and that wheat could be cultivated in sequential rotation in field conditions.
\end{abstract}

Key words: allelopathy; sugar cane; common wheat; germination parameters; biomass; crop rotation
IZVLEČEK

\author{
In vitro ALELOPATSKI UČINKI VODNIH \\ IZVLEČKOV SLADKORNEGA TRSA NA \\ PARAMETRE KALITVE NAVADNE PŠENICE
}

Alelopatija - interakcije med rastlinami za vire preko tekmovanja - je kompleksen fenomen, ki ima za uporabo v kmetijstvu velik pomen. Razumevanje teh interakcij med rastlinami, še posebej med gojenimi, lahko pomaga pri spreminjanju načinov pridelave $\mathrm{z}$ znatnim povečanjem pridelka. V raziskavi so bili preučevani alelopatski učinki vodnih izvlečkov korenin, stebel in listov sladkornega trsa (Saccharum officinale L.), kultivarja 51, v koncentracijah 0 , 2.5, 5.0, 7.5 in $10.0 \mathrm{~g} / \mathrm{l}$ na kalitvene parametere in biomaso kalic krušne pšenice (Triticum aestivum L.), sorte Pirsabak2005. Rezultati so pokazali, da so večje koncentracije $(10.0 \mathrm{~g} / \mathrm{l})$ izvlečkov korenin, stebla in listov značilno zmanjšale povprečni čas kalitve (MGT), a povečale rast semenskih korenin in poganjkov ter biomaso kalic, na odstotek kalitve pa niti koncentracija izvlečkov niti rastlinski organ nista vplivala. Izvlečki v koncentracijah do $7.5 \mathrm{~g} / \mathrm{l}$ niso imeli učinka na preučevane parametre pšenice. Rezultati nakazujejo, da ima sladkorni trs pozitivne alelopatske učinke na rast pšenice in da lahko poljščino gojimo v kolobarju neposredno za sladkornim trsom.

Ključne besede: aleopatija; sladkorni trs; krušna pšenica; biomasa; parametri kalitve; kolobar

\section{INTRODUCTION}

Allelopathy is a composite process occurring in natural habitats as well as in cultivated fields and is generally perceived as a mechanism of plants and microbes' capacity to maintain their dominance over others or at least to coexist in a given environment. Through allelopathy alone or in combination with competition, plants can influence survival capability of in-range plants and other microorganisms in a manner that they are constrained to either migrate to somewhere else or to remain in the habitat in a defensive mode. The

1 Department of Botany, Government Degree College Naguman Peshawar, Peshawar, Khyber Pakhtunkhwa, Pakistan; *Corresponding author: majeedpsh@gmail.com

2 Department of Botany, University of Peshawar, Peshawar, Khyber Pakhtunkhwa, Pakistan

3 Department of Botany, Hazara University Mansehra, Khyber Pakhtunkhwa, Pakistan

4 Islamia College University Peshawar, Peshawar, Khyber Pakhtunkhwa, Pakistan 
influential capacity of one plant over the other is because of the metabolic compounds (known as allelochemicals) they release into the surrounding environments either as volatile substances, rain leachates, decomposed products or direct secretion to rhizosphere with potential negative or positive interactions with other plants and microbes (Barkosky et al., 2000; Barto et al., 2010; Rice, 2012). Allelochemicals are generally secondary metabolites present in different concentrations in different plant parts (leaves, stem, barks, flowers, seeds etc.) which upon release into the rhizosphere tend to modify the resource consumption capacity by several mechanisms i.e., alteration of cell membrane permeability, changing enzymatic activity, triggering genetic defects and disturbing photosynthesis of the competitor plants (Gonzalez and Estevez-Braun, 1997; Wu et al., 2000; Barto et al., 2010; Majeed et al., 2012). Interactions among plants for resources through allelopathy lead to physiological and biochemical modifications which may result in the establishment of a successful plant community by eliminating or restricting the susceptible species, although many plants exhibit positive allelopathic effects on the surrounding plants (Elijarrat and Barcelo, 2001; Maharjan et al., 2007; Hussain et al., 2010). Thus allelopathy may be successfully employed in agriculture for enhancing crop productivity and weed management (Fang et al., 2013).

Common wheat (Triticum aestivum L.) in the family Poaceae is an important agronomic crop widely cultivated for grains which are used in food and several other processed products. After maize and rice, wheat is ranked the third most widely produced grain crops in the world which has significant impact on meeting global food demands and dietary needs (Hou et al., 2014). The crop in Pakistan is generally cultivated in rotation with several other crops such as maize, rice, tobacco and sugarcane. Knowledge about allelopathic nature of preceding crops may be helpful in modifying cultivation pattern of wheat with other crops. During the last few years, allelopathic activities of several plants and agricultural crops including wheat have been rigorously worked out (Khaliq et al., 2013; Muhammad and Majeed, 2014). Sampietro and Vattuone (2006) observed root elongation of some selected weeds and crops at lower concentrations while declined root growth at higher concentration of aqueous extracts of sugarcane straw. Nikneshan et al. (2011) investigated aqueous extracts of air-dried leaf powder of eight cultivars of sunflower for allelopathic activities on wheat with decrease in germination indices at higher extract concentrations. Majeed et al. (2012) observed drastic effects of higher but stimulatory effects of lower concentrations of aqueous extracts of Chenopodium album L. on plant height, tillers, spike length and grain yield of wheat. Variable results were obtained for germination, plant height; fresh and dry mass of shoot and root of wheat under the allelopathic influence of three weeds species viz: Asphodelus tenuifolius Cav., Euphorbia hirta L., and Fumaria indica (Hausskn.) Pugsley (Jabeen et al., 2013). Ullah et al. (2013) recorded suppressive effects on germination of 20 varieties of wheat treated with aqueous leaf extracts of Eucalyptus camaldulensis Dehnh., Acacia nilotica (L.) Willd. ex Delile, Helianthus annuus L. and Parthenium hysterophorus $\mathrm{L}$.

Although sugarcane's allelopathy has been worked out against weeds and some crops; however, reports on its allelopathic investigation against wheat are scarce in literature. The aim of this work was to study the allelopathic activity of root, stem peels and leaves of sugarcane on germination and seedling growth of wheat in laboratory conditions.

\section{MATERIALS AND METHODS}

\subsection{Plant materials}

Mature plants of Sugarcane (Saccharum officinale L.) cultivar 51 were collected at harvesting stage from cultivated fields in Naguman, Peshawar during 2013. Different plants parts i.e., leaves, stem peels and root were separated and dried under shade conditions. Dried parts were ground to powder with an electric grinder for further use. In order to get aqueous extracts of different concentration, 2.5, 5.0, 7.5 and $10.0 \mathrm{~g}$ of dried powder of each part i.e., leaves, stem peels and roots were soaked for $24 \mathrm{~h}$ in 1litre distilled water each at room temperature. The soaked materials were filtered through muslin cloth after 24 hours. Filtrate was again filtered through filter paper (Whatman No. 1) in sterilized flasks to get extracts of different concentrations. Aqueous extracts were stored at $4{ }^{\circ} \mathrm{C}$ in a refrigerator.

\subsection{Bioassay}

Seeds of wheat (Triticum aestivum L.) cultivar Pirsabak2005 were obtained from Agricultural Research Institute, Tarnab, Peshawar. Seeds were placed on twice folded filter paper as seed beds in petri-dishes. Each petri-dish was provided with $10 \mathrm{ml}$ of respective concentrated aqueous extracts. Control seeds were provided with the same volume of distilled water. Each Petri dish had 10 seeds; each treatment was further replicated 4 times. The experiment was arranged in a 
Completely Randomized Manner at room temperature $\left(20-25^{\circ} \mathrm{C}\right)$ with $12 \mathrm{~h}$ photo period. The experiment was performed at Botany Department, Government Degree College Naguman Peshawar during 2013. After 72 hours, data on germination, seminal root and shoot length of seedling was recorded. Germination (\%) was calculated as number of germinated seeds in each replicate after 72 hours till final reading. Mean germination time was determined as: $\mathrm{MGT}=\Sigma(d i \times n i)$ $/ \Sigma n i$; where $n$ represents number of germinated seeds at $\mathrm{i}^{\text {th }}$ day and $d$ is the number of days counted from the beginning till the completion of germination (Basra et al., 2005). Dry biomass of seedling was determined as previously described by Muhammad and Hussain (2012).

\subsection{Statistical analysis}

Results were statistically analyzed by the analysis of variance (ANOVA). Least significant difference (LSD) was used to determine significant mean values of the studied parameters at $\mathrm{p} \leq 0.05$.

\section{RESULTS}

\subsection{Germination (\%)}

In this experiment, the allelopathic activity of root, stem peels and leaves of sugarcane which were prepared as aqueous extracts in different concentrations were studied on germination parameters and dry biomass of wheat. Results revealed that germination percentage was neither affected by different plant parts nor by extract concentrations. Interaction between plant parts and concentrations were also non-significant.
Germination (\%) was maximum (91.8) in control conditions. Slighter decrease in germination was observed in petri-dishes treated with different extract concentrations of different plant parts; however, the differences among means of concentrations and plant parts for germination percentage were insignificant and they ranged between 89.7 - $90.9 \%$ which did not differ significantly from $91.8 \%$ in control (Table 1 ).

Table 1: Effect of different concentrations of aqueous extracts of plant parts (root, stem peel and leaves) of sugarcane on germination $(\%)$ of wheat

\begin{tabular}{l|rrrrr|l}
\hline \multirow{2}{*}{ Plant parts } & \multicolumn{5}{|c|}{ Concentration $(\mathrm{g} / \mathrm{l})$} & \multirow{2}{*}{ Plant parts means } \\
\cline { 2 - 6 } & Control 0 & 2.5 & 5.0 & 7.5 & 10.0 & \\
\hline Roots & $91.8 \mathrm{a}$ & $90.9 \mathrm{a}$ & $90.7 \mathrm{a}$ & $90.9 \mathrm{a}$ & $91.4 \mathrm{a}$ & $90.98 \mathrm{a}$ \\
Stem peel & $91.8 \mathrm{a}$ & $90.7 \mathrm{a}$ & $91.1 \mathrm{a}$ & $90.9 \mathrm{a}$ & $91.0 \mathrm{a}$ & $91.10 \mathrm{a}$ \\
Leaves & $91.8 \mathrm{a}$ & $90.8 \mathrm{a}$ & $90.9 \mathrm{a}$ & $90.7 \mathrm{a}$ & $89.7 \mathrm{a}$ & $90.64 \mathrm{a}$ \\
& & & & & & \\
Concentration means & $91.8 \mathrm{a}$ & $90.8 \mathrm{a}$ & $90.9 \mathrm{a}$ & $90.83 \mathrm{a}$ & $90.7 \mathrm{a}$ & \\
\hline
\end{tabular}

\subsection{Mean Germination Time}

MGT was calculated to assess the average number of days taken from the beginning of germination of seeds till completion of germination. MGT was significantly affected by plant parts as well as concentration of extracts. Interaction between plant parts and concentration was also recorded as significant. It was observed that lower extract concentrations up to $7.5 \mathrm{~g} / \mathrm{l}$ of each plant part had no effect on this parameter; however, $10.0 \mathrm{~g} / \mathrm{l}$ extract significantly minimized germination time particularly when roots and peel extracts were applied (Table 2). Leaf extract at the highest dose $(10 \mathrm{~g} / \mathrm{l})$ significantly prolonged meant time of germination which was recorded as 5.8 days. In each plant part at highest extract concentration, MGT was lowest than control where it was 4.7 days except in leaf extract which revealed maximum value for this parameter.

\subsection{Shoot growth}

Analysis of variance (ANOVA) determined significant differences for values of shoot length of wheat seedlings at $10 \mathrm{~g} / \mathrm{l}$ concentrated extracts but insignificant effect at lower concentrations. Interactions were also significant. Shoot length was $15.9 \mathrm{~mm}$ in control plates which were treated with distilled water. There were no significant differences between values in extract concentrations 2.5, 5 and $7.5 \mathrm{~g} / \mathrm{l}$ of respective plant parts which revealed results almost consistent with those of control; however, $10 \mathrm{~g} / \mathrm{l}$ extract of root and stem peels significantly increased shoot length (16.8 and $16.7 \mathrm{~mm}$ respectively). Unexpectedly, the same concentrated extract of leaves had adverse effect on shoot growth which was significantly reduced $(14.2 \mathrm{~mm})$ as compared to control and other plant part extracts (Table 3 ). 
Abdul MAJEED et al.

Table 2: Effect of different concentrations of aqueous extracts of plant parts (root, stem peel and leaves) of sugarcane on mean germination time (MGT) (days) of wheat

\begin{tabular}{l|rrrrrr|l}
\hline \multirow{2}{*}{ Plant parts } & \multicolumn{5}{|c|}{ Concentration $(\mathrm{g} / \mathrm{l})$} & \multirow{2}{*}{ Plant parts means } \\
\cline { 2 - 6 } & Control 0 & 2.5 & 5.0 & 7.5 & 10.0 & \\
\hline Roots & $4.7 \mathrm{a}$ & $4.3 \mathrm{a}$ & $4.6 \mathrm{a}$ & $4.8 \mathrm{a}$ & $3.4 \mathrm{c}$ & $4.36 \mathrm{a}$ \\
Stem peel & $4.7 \mathrm{a}$ & $4.4 \mathrm{a}$ & $4.7 \mathrm{a}$ & $4.9 \mathrm{a}$ & $3.7 \mathrm{~b}$ & $4.48 \mathrm{a}$ \\
Leaves & $4.7 \mathrm{a}$ & $4.8 \mathrm{a}$ & $4.8 \mathrm{a}$ & $4.9 \mathrm{a}$ & $5.8 \mathrm{bc}$ & $4.4 \mathrm{a}$ \\
& $4.7 \mathrm{a}$ & $4.5 \mathrm{a}$ & $4.7 \mathrm{a}$ & $4.86 \mathrm{a}$ & $3.3 \mathrm{c}$ & \\
\multicolumn{2}{l|}{ Concentration means } & & & & & \\
\hline
\end{tabular}

$\operatorname{LSD}(\mathrm{p} \leq 0.05)$ for plant parts $=3.245$; concentration $=2.769$; interaction 3.120

Values in columns and rows with different alphabets are significantly different

Table 3: Effect of different concentrations of aqueous extracts of plant parts (root, stem peel and leaves) of sugarcane on shoot length $(\mathrm{mm})$ of wheat

\begin{tabular}{l|rrrrrl|l}
\hline \multirow{2}{*}{ Plant parts } & \multicolumn{5}{|c|}{ Concentration $(\mathrm{g} / \mathrm{l})$} & \multirow{2}{*}{ Plant parts means } \\
\cline { 2 - 6 } & Control 0 & 2.5 & 5.0 & 7.5 & 10.0 & \\
\hline Roots & $15.9 \mathrm{a}$ & $16.0 \mathrm{a}$ & $15.9 \mathrm{a}$ & $15.3 \mathrm{a}$ & $16.8 \mathrm{~b}$ & $90.98 \mathrm{a}$ \\
Stem peel & $15.9 \mathrm{a}$ & $15.8 \mathrm{a}$ & $15.7 \mathrm{a}$ & $15.5 \mathrm{a}$ & $16.7 \mathrm{~b}$ & $91.1 \mathrm{a}$ \\
Leaves & $15.9 \mathrm{a}$ & 15.4 & $15.6 \mathrm{a}$ & $15.7 \mathrm{a}$ & $14.2 \mathrm{bc}$ & $90.64 \mathrm{a}$ \\
& & & & & & \\
Concentration means & $15.9 \mathrm{a}$ & $15.8 \mathrm{a}$ & $15.7 \mathrm{a}$ & $15.5 \mathrm{a}$ & $15.9 \mathrm{a}$ & \\
\hline
\end{tabular}

LSD $(p \leq 0.05)$ for plant parts $=1.971$; concentration $=3.963$; interaction 4.7612

Values in columns and rows with different alphabets are significantly different

\subsection{Seminal root length}

Like other indices, seminal root length was significantly influenced by concentrations of the extracts as well as different plant parts. Lower concentration had no effect on RL whose values were similar to control with slight variations. Interaction between plant parts and concentrations at highest dose were significant. Control condition and extract concentrations up to $7.5 \mathrm{~g} / \mathrm{l}$ recorded almost similar values of seminal root length which ranged between 27.3-27.9 mm. Maximum length $(30.1 \mathrm{~mm})$ of seminal root was observed in root extract at $10 \mathrm{~g} / \mathrm{l}$ concentration followed by the same extract concentration of stem peels and leaves which yielded consistent values 29.4 and $29.3 \mathrm{~mm}$ respectively (Table $4)$.

\subsection{Seedling dry biomass}

Dry biomass of seedling was calculated in each replicate of each treatment and then averaged to determine individual seedling's biomass. Results demonstrated significantly different values for different plant parts, $10 \mathrm{~g} / \mathrm{l}$ extract concentration and interactions but insignificant differences were observed for lower concentrations $(2.5-7.5 \mathrm{~g} / \mathrm{l})$. Values of dry biomass slightly varied under lower extract concentrations of each plant part; however, they were statistically similar to control values. Root and stem peels extract at $10 \mathrm{~g} / \mathrm{l}$ resulted in highest dry biomass of seedlings which were recorded as 40.1 and $39.2 \mathrm{mg}$ respectively when compared to control (36.1 mg). The lowest value for dry biomass was observed in $10 \mathrm{~g} / \mathrm{l}$ leaves extract which was $34.2 \mathrm{mg}$, significantly different from control as well as root and peel extracts at the same concentration (Table 5). 
Table 4: Effect of different concentrations of aqueous extracts of plant parts (root, stem peel and leaves) of sugarcane on seminal root length $(\mathrm{mm})$ of wheat

\begin{tabular}{l|rrrrrll}
\hline \multirow{2}{*}{ Plant parts } & \multicolumn{5}{|c|}{ Concentration $(\mathrm{g} / \mathrm{l})$} & \multirow{2}{*}{ Plant parts means } \\
\cline { 2 - 6 } & Control 0 & 2.5 & 5.0 & 7.5 & 10.0 & \\
\hline Roots & $27.8 \mathrm{a}$ & $27.7 \mathrm{a}$ & $27.6 \mathrm{a}$ & $28.0 \mathrm{a}$ & $30.1 \mathrm{~b}$ & $28.4 \mathrm{a}$ \\
Stem peel & $27.8 \mathrm{a}$ & $27.5 \mathrm{a}$ & $27.7 \mathrm{a}$ & $27.9 \mathrm{a}$ & $29.4 \mathrm{~b}$ & $28.06 \mathrm{a}$ \\
Leaves & $27.8 \mathrm{a}$ & $27.3 \mathrm{a}$ & $27.4 \mathrm{a}$ & $27.8 \mathrm{a}$ & $29.3 \mathrm{~b}$ & $27.9 \mathrm{a}$ \\
& & & & & \\
Concentration means & $27.8 \mathrm{a}$ & $27.5 \mathrm{a}$ & $27.5 \mathrm{a}$ & $27.9 \mathrm{a}$ & $29.6 \mathrm{~b}$ & \\
\hline \multicolumn{2}{l}{ LSD $(\mathrm{p} \leq 0.05)$ for plant parts $=11.09 ;$ concentration $=7.939 ;$ interaction 1.890}
\end{tabular}

Values in columns and rows with different alphabets are significantly different

Table 5: Effect of different concentrations of aqueous extracts of plant parts (root, stem peel and leaves) of sugarcane on dry biomass seedling ${ }^{-1}(\mathrm{~g})$ of wheat

\begin{tabular}{l|rrrrrr|}
\hline \multirow{2}{*}{ Plant parts } & \multicolumn{5}{|c|}{ Concentration $(\mathrm{g} / \mathrm{l})$} & \multirow{2}{*}{ Plant parts means } \\
\cline { 2 - 6 } & Control 0 & 2.5 & 5.0 & 7.5 & 10.0 & \\
\hline Roots & $36.1 \mathrm{a}$ & $35.8 \mathrm{a}$ & $36.9 \mathrm{a}$ & $36.5 \mathrm{a}$ & $40.1 \mathrm{~b}$ & $37.08 \mathrm{c}$ \\
Stem peel & $36.1 \mathrm{a}$ & $36.4 \mathrm{a}$ & $36.3 \mathrm{a}$ & $36.9 \mathrm{a}$ & $39.2 \mathrm{~b}$ & $36.98 \mathrm{a}$ \\
Leaves & $36.1 \mathrm{a}$ & $36.7 \mathrm{a}$ & $36.4 \mathrm{a}$ & $36.7 \mathrm{a}$ & $34.2 \mathrm{c}$ & $36.02 \mathrm{a}$ \\
& & & & & & \\
Concentration means & $36.1 \mathrm{a}$ & $36.3 \mathrm{a}$ & $36.5 \mathrm{a}$ & $36.7 \mathrm{a}$ & $37.8 \mathrm{ab}$ & \\
\hline
\end{tabular}

LSD $(\mathrm{p} \leq 0.05)$ for plant parts $=5.213 ;$ concentration $=1.7821 ;$ interaction 6.379

Values in columns and rows with different alphabets are significantly different

\section{DISCUSSION}

Germination is an important indicator which depicts the plants' response to changes in the environment, resources or any allelopathic stress induced as a result of allelochemicals released from donor plants (Hussain et al., 2010). Germination indices are generally used to detect potential stimulatory or inhibitory allelopathic activity of the test plant (Hussain and Reigosa, 2014). In our study, germination percentage was not affected by aqueous extract of different plant parts of $S$. officinale. Moreover, concentrations of the extracts were also unable to stimulate or inhibit the germination percentage of wheat. This is in contradiction with previous studies on the allelopathy of Hypericum myrianthum Cham. \& Schltdl. (Fritz et al., 2007), Eucalyptus camaldulensis (Ahmed et al., 2008), Prosopis juliflora (Sw.) DC. (Siddiqui et al., 2009), Dodonaea viscosa Jacq. (Barkatullah et al., 2010) and Halianthus annus L. (Muhammad and Majeed, 2014) on germination of wheat and other target crops which revealed significant retardation of germination under the allelopathy of the respective plants at different extract concentrations. We used the highest concentration as 10 $\mathrm{g}^{-1}$ which is relatively low as compared to extract concentrations used in other studies. Thus, nonresponsiveness of seed germination to alleopathic stress in this study might be due to relatively low concentration or possible resistance exhibited by wheat seeds to potential allelopathic activity of sugarcane.

Mean germination time (MGT) is another important parameter which determines the energy of germination capacity of seeds in a stressed environment (Bonciarelli, 1995). MGT of target plants in a particular allelopathic assay may either be increased or decreased, depending on the concentration and type of allelopathic compounds. Phenolic compounds, in general, have been sought to prolong germination time as they may possibly interfere with seed dormancy and enzymatic activity necessary for rapid germinability. In this study, MGT was significantly reduced by root and peel extracts at $10 \mathrm{~g} / \mathrm{l}$ concentration but prolonged under leaves extract. This suggest that root and peels extracts of sugarcane have some potent alleochemicals with stimulatory effect on germination time. On the other hand, leaves extract may possibly possess phenolics which had detrimental effect on this parameter. 
Previously, Sampietro \& Vattuone (2006) isolated phenolic compounds from straw of sugarcane which had deteriorating effects on germination and general growth of different weeds and crops.

Shoot and seminal root growth were significantly increased by root and stem peels extract at higher concentration which demonstrated stimulatory allelopathy of sugarcane. We assume that root and peel extracts of sugarcane may contain carbohydrates complexes and unknown diffusible allelochemicals which induced stimulatory response in wheat seedling with consequent increase in shoot and seminal root length. However, leaf extract showed detrimental effects on the lengths of shoot and seminal root. Previously stimulatory effect of rice hull extracts (Seyyednejad et al., 2010) but inhibitory effect of Jatropha curcas L. (Aburge and Sam, 2010), Dodonaea viscosa (Barkatullah et al., 2010) and oleander and walnut leaf extracts (Unal, 2013) on shoot length of different plants including wheat have been reported. Similarly, our results regarding reduced shoot and seminal root length under leaf extracts are in line with findings of Batlang and Shusho (2007), Singh et al. (2009), Sadehgi et al. (2010) and Unal (2013) who reported shoot and seminal root suppression of wheat in response to aqueous extracts of different allelopathic plants. Primary effect of allelochemicals may probably be alteration in cell membrane permeability of the target plant which can cause secondary effects such as changes in water and mineral absorptions potentials, changes in $\mathrm{pH}$, enzymatic alterations etc. thus causing either stimulatory or inhibitory effects (Barkosky et al. 2000; Gatti et al., 2010; Majeed et al., 2012). Allelopathic stress may either elevate the level or induce the inhibition of carbohydrates and protein contents of target plant which build up more proline content as stress indicator; consequently plant growth is either increased or reduced (Batish et al., 2007; Al-Johani et al., 2012).

Increase in dry biomass was observed under allelopathic effects of $10 \mathrm{~g} / \mathrm{l}$ root and peel extract which are supported by the findings of Mubeen et al. (2012) on barley and Han et al. (2013) on lettuce who documented increase in dry biomass in response to alleopathic aqueous extracts of diverse plants. Decrease in biomass of seedlings treated with leaf extracts in this study are in agreement with Singh et al. (2005), Jamil et al. (2009), Ullah et al. (2013) and Jabeen et al. (2013) who reported suppression in fresh and dry biomass of seedling in Brassica sp., wild oat and wheat under the influence of allelopathy of some weeds and crops. Differences in results of different studies may be due to different experimental conditions, extract concentrations and test plants they used. The increase in dry biomass of wheat seedlings treated with root and stem peel extract in the current study may probably be due to increase in photosynthetic rate and greater accumulation of photoassimilate in the shoot, increase in thickness and length of seminal root, decrease in proline content and greater potassium ion uptake induced by allelopathic extracts of S. officinale; as in earlier studies some authors argued that botanical extracts could have positive influence on these phenomena thus stimulating biomass of the receptor plant (Rizvi and Rizvi, 1992; Gatti et al., 2010; Ibrahim et al., 2013). Similarly, reduced biomass, seminal root and shoot length under leaf extract suggests the presence of phenolic and growth inhibitory compounds in leaves of sugarcane and these reductions may be regarded as a result of induced oxidative damage and activation of cellular anti- oxidant systems which in turn changed permeability patterns of cell membrane, irregularities in mineral and ion uptake and the activation of stress enzymes (Oracz et al., 2007; Khaliq et al., 2012).

\section{CONCLUSION}

The present study suggests that different plant parts of sugarcane exhibit both stimulatory and inhibitory allelopathy against wheat in germination bioassay. Roots and stem peel extracts at higher concentration promoted germination time, shoot and seminal root growth and dry biomass of seedling while leaf extract had negative effects on these parameters. Pot culture study is underway to confirm our lab bioassay findings.

\section{REFERENCES}

Abugre, S. \& Sam, S.J. (2010). Evaluating the allelopathic effect of Jatropha curcas aqueous extract on germination, radicle and plumule length of crops. International Journal of Agriculture and Biology, 12, 769-772.
Ahmed, R., Hoque, A.T.R., \& Hossain, M.K. (2008). Allelopathic effects of leaf litters of Eucalyptus camaldulensis on some forest and agricultural crops. Journal of Forestry Research, 19(1), 19-24. doi:10.1007/s11676-008-0003-x 
Al-Johani, N.S., Aytah, A.A., \& Boutraa, T. (2012). Allelopathic impact of two weeds on growth and photosynthesis of barley (Hordeum vulgare L.). Pakistan Journal of Botany, 44(6), 1865-1872.

Barkatullah, Hussain, F., \& Ibrar. M. (2010). Allelopathic potential of Dodonaea viscosa (L.) Jacq. Pakistan Journal of Botany, 42(4), 23832390.

Barkosky, R.R., Einhellig, F.A., \& Butler, J.L. (2000). Caffeic acid-induced changes in plant-water relationships and photosynthesis in leafy spurge Euphorbia esula. Journal of Chemical Ecology, 26(9), 2095-2109. doi:10.1023/A:1005564315131

Barto, K., Friese, C., \& Dipollini, D. (2010). Arbuscular mycorrhizal fungi protect a native plant from allelopathic effects of an invader. Journal of Chemical Ecology, 36(4), 351-360. doi:10.1007/s10886-010-9768-4

Basra, S.M.A., Farooq, M., Tabassam, R., \& Ahmad, N. (2005). Physiological and biochemical aspects of pre-sowing seed treatments in fine rice (Oryza sativa L.). Seed Science and Technology, 33(3), 623-628. doi:10.15258/sst.2005.33.3.09

Batish, D.R., Lavanya, K., Singh, H.P., \& Kohli, R.K. (2007). Phenolic allelochemicals released by Chenopodium murale affect the growth, nodulation and macromolecule content in chickpea and pea. Plant Growth Regulation, 51(2), 119-128. doi:10.1007/s10725-006-9153-z

Batlang, U., \& Shushu, D.D. (2007). Allelopathic activity of sunflower (Helianthus annuиs L.) on growth and nodulation of bambara groundnut (Vigna subterranea (L.) Verdc.). Journal of Agronomy, $6 \quad$ (4), 541-547. doi:10.3923/ja.2007.541.547

Bonciarelli, F. (1995). Fondamenti di Agronomia Generale. Ed. Agricole, Bologna, Italy, pp. 372.

Eljarrat, E., \& Barcelo, D. (2001). Sample handling and analysis of allelochemical compounds in plants. Trends in Analytical Chemistry, 20(10), 584-590. doi:10.1016/S0165-9936(01)00104-2

Fang, C., Zhuang, Y., Xu, T., Li, Y., \& Lin, W. (2013). Changes in rice allelopathy and rhizosphere microflora by inhibiting rice phenylalanine ammonia-lyase gene expression. Journal of Chemical Ecology, 39(2), 204-212. doi:10.1007/s10886-013-0249-4

Fritz, D., Bernardi, A.P., Haas, J.S., Ascoli, B.M., Bordignon, S.A.D.L., \& Von Poser, G. (2007). Germination and growth inhibitory effects of Hypericum myrianthum and $H$. polyanthemum extracts on Lactuca sativa L. Revista Brasileira de
Farmacognosia, 17(1), 44-48. doi:10.1590/S0102695X2007000100010

Gatti, A.B., Ferreira, A.G., Arduin, M., \& Perez, S.C. (2010). Allelopathic effects of aqueous extracts of Artistolochia esperanzae O. Kuntze on development of Sesamum indicum L. seedlings. Acta Botanica Brasilica, 24(2), 454-461. doi:10.1590/S0102-33062010000200016

Gonzalez, J.A., \& Estevez-Braun, A. (1997). Phytonematicidal activity of aromatic compounds related to shikimate pathway. Pesticide Biochemistry and Physiology, 58(3): 193-197. doi:10.1006/pest.1997.2294

Han, X., Cheng, Z., Meng, H.U., Yang, Y., \& Ahmad, I. (2013). Allelopathic effect of decomposed garlic (Allium sativum L.) stalk on lettuce ( $L$. sativa var. crispa). Pakistan Journal of Botany, 45(1), 225233.

Hou, J., Jiang, Q., Hao, C., Wang, Y., Zhang, H., \& Zhang, X. (2014). Global selection on sucrose synthase haplotypes during a century of wheat breeding. Plant Physiology, 164(4), 1918-1929. doi:10.1104/pp.113.232454

Hussain, F., Ahmad, B., \& Ilahi, I. (2010). Allelopathic effects of Cenchrus ciliaris L. and Bothriochloa pertusa (L.) A. Camus. Pakistan Journal of Botany, 42, 3587-3604.

Hussain, M.I., \& Reigosa, M.J. (2014). Evaluation of herbicide potential of sesquiterpene lactone and flavonoid: impact on germination, seedling growth indices and root length in Arabidopsis thaliana. Pakistan Journal of Botany, 46, 995-1000.

Ibrahim, M., Ahmad, N., Shinwari, Z.K., Bano, A., \& Ullah, F. (2013). Allelopathic assessment of genetically modified and non-modified maize (Zea mays L.) on physiology of wheat (Triticum aestivum L.). Pakistan Journal of Botany, 45(1), 235-240.

Jabeen, N., Ahmed, M., Shaukat, S.S., \& Iram-us-Slam. (2013). Allelopathic effects of weeds on wheat (Triticum aestivum L.) germination and growth. Pakistan Journal of Botany, 45(3), 807-811.

Jamil, M., Cheema, Z.A., Mushtaq, M.N., Farooq, M., \& Cheema, M.A. (2009). Alternative control of wild oat and canary grass in wheat fields by allelopathic plant water extracts. Agronomy for Sustainable Development, 29(3), 475-482. doi:10.1051/agro/2009007

Khaliq, A., Matloob, A., Aslam, F., Mushtaq, M.N., \& Khan, M.B. (2012). Toxic action of aqueous wheat straw extract on horse purslane. Planta Daninha, 


\section{0(2), 269-278. doi:10.1590/S0100- 83582012000200005}

Khaliq, A., Matloob, A., Khan, M.B., \& Tanveer, A. (2013). Differential suppression of rice weeds by allelopathic plant aqueous extracts. Planta Daninha, 31(1), 21-28. doi:10.1590/S010083582013000100003

Maharjan, S., Shrestha, B.B., \& Jha, P.K. (2007). Allelopathic effects of aqueous extract of leaves of Parthenium hysterophorus L. on seed germination and seedling growth of some cultivated and wild herbaceous species. Scientific World, 5(5): 33-39.

Majeed, A., Chaudhry, Z., \& Muhammad, Z. (2012). Aallelopathic assessment of fresh aqueuous extracts of Chenopodium album L. for growth and yield of wheat (Triticum aestivum L.). Pakistan Journal of Botany, 44(1), 165-167.

Mubeen, K., Nadeem, M.A., Tanveer, A., \& Zahir, Z.A. (2012). Allelopathic effects of sorghum and sunflower water extracts on germination and seedling growth of rice (Oryza sativa L.) and three weed species. Journal of Animal and Plant Science, 22(3), 738-746.

Muhammad, Z., \& Majeed, A. (2014). Allelopathic effects of aqueous extracts of sunflower on wheat (Triticum aestivum L.) and maize (Zea maize L.). Pakistan Journal of Botany, 46(5), 1715-1718.

Muhammad, Z., \& Hussain, F. (2012). Effect of $\mathrm{NaCl}$ salinity on the germination and seedling growth of seven wheat genotypes. Pakistan Journal of Botany, 44(6), 1845-1850.

Nikneshan, P., Karimmojeni, H., Moghanibashi, M., \& Hosseini, N. (2011). Allelopathic potential of sunflower on weed management in safflower and wheat. Australian Journal of Crop Science, 5(11), 1434-1440.

Oracz, K., Bailly, C., Gniazdowska, A., Come, D., Corbineau, F., \& Bogatek, R. (2007). Induction of oxidative stress by sunflower phytotoxins in germinating mustard seeds. Journal of Chemical Ecology, 3(2), 251-264. doi:10.1007/s10886-0069222-9

Rice, E.L. (2012). Allelopathy: Physiological Ecology. Academic Press, Inc. USA. Pp.1

Rizvi, S.J.H., \& Rizvi, V. (1992). Allelopathy: Basic and Applied Aspects. London, Chapman \& Hall. Pp. 480. doi:10.1007/978-94-011-2376-1
Sadeghi, S., Rahnavard, A., \& Ashrafi, Z.Y. (2010). Response of wheat (Triticum aestivum) germination and growth of seedling to allelopathic potential of sunflower (Helianthus annuus) and barley (Hordeum vulgare L.) extracts. Journal of Agricultural Technology, 6, 573-577.

Sampietro, D.A., \& Vattuone, M.A. (2006). Sugarcane straw and its phytochemicals as growth regulators of weed and crop plants. Plant Growth Regulation, 48(1), 21-27. doi:10.1007/s10725-005-5135-9

Seyyednejad, S.M., Koochak, H., Najafabade, F.P., \& Kolahi, M. (2010). Allelopathic effect of aquatic hull extract of rice (Oryza sativa L.) on growth of Silybum marianum and Echinochloa crus-galli. African Journal of Agricultural Research, 5(16), 2222-2226.

Siddiqui, S., Bhardwaj, S., Khan, S.S., \& Meghvanshi, M.K. (2009). Allelopathic effect of different concentration of water extract of Prosopis juliflora leaf on seed germination and radicle length of wheat (Triticum aestivum Var-Lok-1). AmericanEurasian Journal of Scientific Research, 4(2), 8184.

Singh, B., Vikaspal, S., \& Kumar, M. (2009). Effect of Tinospora cordifolia aqueous extract on traditional food crops of Garhwal Himalaya. International Journal of Sustainable Agriculture, 1(2), 36-40.

Singh, H.P., Batish, D.R., Pandher, J.K., \& Kohli, R.K. (2005). Phytotoxic effects of Parthenium hysterophorus residues on three Brassica species. Weed Biology and Management, 5(3), 105-109. doi:10.1111/j.1445-6664.2005.00172.x

Ullah, A., Khan, E.A., Baloch, M.S., Nadim, M.A., Sadiq, M., \& Noor, K. (2013). Allelopathic effect of herbaceous and woody plants species on seed germination and seedling growth of wheat. Pakistan Journal of Weed Science Research, 19(3), 357-375.

Unal, B.T. (2013). Effects of growth regulators on seed germination, seedling growth and some aspects of metabolism of wheat under allelochemical stress. Bangladesh Journal of Botany, 42(1), 65-72. doi:10.3329/bjb.v42i1.15865

Wu, H., Pratley, J., Lemerle, D., \& Haig, T. (2000). Evaluation of seedling allelopathy in 453 wheat (Triticum aestivum) accessions against annual ryegrass (Lolium rigidum) by the equalcompartment-agar method. Crop and Pasture Science, 51(7), 937-94. doi:10.1071/AR00017 